\title{
Persepsi Mahasiswa dan Kepatuhan Pembayaran Pajak Kendaraan di Kota Samarinda
}

\author{
Praja Hadi Saputra \\ Program Studi Manajemen, Universitas Muhammadiyah Kalimantan Timur \\ e-mail: praja.hs@umkt.ac.id
}

\section{3}

Submitted: FEBRUARI 2021

Accepted: JULI 2021

\begin{abstract}
This study aims to investigate the perception of compliance of individual vehicle taxpayers in paying their vehicle taxes which are influenced by individual internal factors. Internal factors used are the level of tax understanding, perceptions about the tax system and government, the effectiveness of the tax system as well as the ethical perceptions that individuals have. The results of the survey through questionnaires and data analysis from 93 multiple linear regressions indicated that the internal factors that individuals had regarding the perception of vehicle tax tended to affect their compliance with paying vehicle taxes. The results of this study then have practical implications on the availability of evidence for the government to design relevant vehicle tax systems and regulations because it can give rise to the perception of obedient individuals in paying their vehicle taxes.
\end{abstract}

Keywords: tax compliance, tax system, tax regulation, tax ethics, vehicle tax

Kata Kunci: kepatuhan pajak, sistem pajak, peraturan pajak, etika perpajakan, pajak kendaraan

\section{PENDAHULUAN}

Sebagai sebuah negara yang masuk dalam kategori berkembang (emerging country), Indonesia saat ini sedang melakukan pembenahan untuk pembangunan di segala sektor yang tentunya memerlukan pembiayaan yang mumpuni sehingga pemerintah dapat melaksanakan rencana pembangunan yang sudah ditetapkan. Pembiayaan yang dibutuhkan untuk kegiatan pembangunan tersebut biasanya bersumber dari penerimaan pajak negara maupun penerimaan bukan pajak. Pajak adalah penerimaan negara yang berasal dari pungutan wajib pemerintah kepada rakyat yang nantinya akan digunakan untuk kepentinyan negara. Mardiasmo (2011) mendefiniskan pajak sebagai iuran rakyat kepada kas negara berdasarkan undang-undang yang sifatnya dipaksakan dengan tidak mendapat jasa imbalan (kontraprestasi) yang langsung dapat ditunjukkan dan yang

\section{JIAKES}

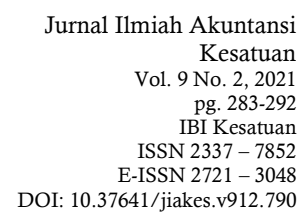
Kesatuan Vol. 9 No. 2, 2021 pg. 283-292 IBI Kesatuan ISSN $2337-7852$
E-ISSN $2721-3048$ DOI: 10.37641 /jiakes.v912.790 
Tax Compliance and Its Perception Among Students digunakan untuk membayar pengeluaran umum. Definisi lain diungkapkan oleh Siahaan (2013) yang menyebutkan bahwa pajak adalah pungutan dari masyarakat oleh negara (pemerintah) berdasarkan undang-undang yang bersifat memaksa, dan terutang oleh yang wajib membayarnya dengan tidak mendapat imbalan secara langsung, dimana hasilnya nanti digunakan untuk membiayai pengeluaran negara dalam penyelenggaraan pemerintah dan pembangunan.

Undang-undang No. 28 Tahun 2007 menjelaskan bahwa bajak adalah kontribusi wajib kepada negara oleh orang pribadi atau badan yang bersifat memaksa berdasarkan pada undang-undang untuk digunakan sebagai pemenuhan keperluan negara dalam memakmurkan rakyat. Sehingga dapat disimpulkan bahwa pajak memiliki peranan penting dalam pembangunan serta peningkatan kesejahteraan masyarakat serta mendukung realisasi program-program pemerintah. Penelitian ini berfokus pada jenis pumungatan pajak yang bersumber dari masyarakat yang memiliki kendaraan atau biasa disebut dengan pajak kendaraan bermotor. Pajak Kendaraan Bermotor adalah pajak atas kepemilikan dan/atau penguasaan kendaraan bermotor. Kendaraan Bermotor adalah semua kendaraan beroda beserta gandengannya yang digunakan di semua jenis jalan darat, dan digerakkan oleh peralatan teknik berupa motor atau peralatan lainnya yang berfungsi untuk mengubah suatu sumber daya energi tertentu menjadi tenaga gerak kendaraan bermotor yang bersangkutan, termasuk alat-alat berat dan alat-alat besar yang dalam operasinya menggunakan roda dan motor dan tidak melekat secara permanen serta kendaraan bermotor yang dioperasikan di air (UU No. 28 Tahun 2009).

Penelitian ini selanjutnya mencoba untuk mengobservasi faktor-faktor penentu yang menjadi motivasi untuk meningkatkan kepatuhan pembayaran pajak kendaraan oleh mahasiswa. Pendapat Arum (2012) menerangkan bahwa kesadaran para wajib pajak (termasuk pajak kendaraan) sangat diperlukan karena tinggi rendahnya kepatuhan membayar pajak sangat bergantung pada faktor kesadaraan akan perpajak yang ada. Berdasarkan hal tersebut, peneliti ingin memberikan penjelasan bagaimana kepatuhan pembayaran pajak kendaraan dapat ditingkatkan melalui investigasi faktor-faktor internal individu (pada mahasiswa) seperti persepsi tentang efektifitas sistem perpajakan, pengetahuan dan pemahaman tentang peraturan pajak, kepercayaan terhadap sistem hukum dan pemerintah serta faktor etika perpajakan yang dimiliki oleh mahasiswa. Tujuan khusus penelitian ini adalah untuk menjelaskan bagaimana hubungan faktorfaktor internal individu mahasiswa seperti persepsi efektifitas sistem perpajakan, pemahaman peraturan perpajakan, kepercayaan terhadap hukum dan pemerintah, dan etika perpajakan terhadap kepatuhan membayar pajak kendaraan.

\section{Pengembangan Hipotesis}

Hubungan Persepsi Efektifitas Sistem Perpajakan dengan Kepatuhan Membayar Pajak Kendaraan Bermotor. Persepsi terhadap sistem perpajakan merupakan pandangan dari dalam diri individu masyarakat tentang bagaimana keadaan sistem perpajakan yang diterapkan oleh pemangku kebijakan atau pemerintah. Baik atau buruknya pandangan tersebut sangat bergantung pada efektifitas yang terlaksana dan nantinya akan mempengaruhi kemauan para wajib pajak untuk membayar kewajiban mereka. Efektifitas sistem yang diterapkan oleh pemerintah dalam perpajakan memegang peranan penting untuk meningkatkan kepatuhan wajib pajak melalui persepsi yang dirasakan oleh para wajib pajak. Indrawan (2014) dalam penelitiannya menghasilkan bukti bahwa efektifitas sistem perpajakan yang baik mampu membuat wajib pajak semakin sadar akan pentingnya membayar pajak. Keterdukungan hasil juga ditemukan oleh Nuzul (2015) yang menunjukkan bahwa tingkat keefektifan sistem perpajakan berpengaruh secara signifikan terhadap keingginan untuk membayar pajak (willingness to pay taxes). Hubungan antara persepsi efektifitas sistem pajak kendaraan dengan kepatuhan mahasiswa membayar pajak kendaraannya dapat dihipotesiskan sebagai berikut: $\mathrm{H}_{1}$ : Persepsi mahasiswa tentang efektifitas sistem pajak yang baik berpengaruh positif terhadap kepatuhan mahasiswa dalam pembayaran pajak kendaraan bermotor. 
Hubungan Pengetahuan dan Pemahaman Peraturan Perpajakan dengan Kepatuhan Membayar Pajak Kendaraan Bermotor. Sebagai warga negara yang baik, wajib pajak dituntut memiliki pengetahuan dan pemahaman tentang peraturan perpajakan. Pengetahuan dan pemahaman tersebut berkaitan dengan semua tentang perpajakan yang telah diatur oleh pemerintah. Pemahaman dan pengetahuan memadai yang dimiliki oleh para wajib pajak tentang peraturan perpajakan akan berhubungan dengan pemenuhan segala hak dan kewajiban mereka. Ghoni (2012) menyebutkan, pengetahuan wajib pajak berkaitan dengan kedisiplinan wajib pajak dalam membayarkan pajaknya, karena kedisiplinan berdasar pada tingkat pemahaman yang sesuai pada tingkat hukum pajak yang dianut suatu negara serta sanksi-sanksi yang menyertainya. Syahril (2013) mengatakan bahwa jika pengetahuan wajib pajak mengenai perpajakan rendah, maka kepatuhan wajib pajak mengenai peraturan yang berlaku juga rendah, karena walaupun wajib pajak tidak berniat untuk melalaikan kewajiban pajaknya, wajib pajak tetap tidak mampu memenuhi kewajiban perpajakannya karena dia sendiri tidak memahami undang-undang dan tata cara perpajakan, hal ini akan mengakibatkan kepatuhan wajib pajak menjadi rendah. Dalam penelitiannya, Syahril (2013) memperoleh hasil bahwa tingkat pemahaman wajib pajak berpengaruh signifikan positif terhadap tingkat kepatuhan wajib pajak. Semakin tinggi tingkat pemahaman wajib pajak maka tingkat kepatuhan wajib pajak dalam memenuhi kewajiban perpajakannya juga akan semakin tinggi. Berdasarkan uraian tersebut, maka penelitian ini mengajukan hipotesis tentang pemahaman dan pengetahuan perpajakan yang dimiliki oleh wajib pajak (mahasiswa) khususnya pajak kendaraan bermotor sebagai berikut: $\mathrm{H}_{2}$ : Tingkat pemahaman dan pengetahuan tentang peraturan perpajakan mahasiswa berpengaruh positif terhadap kepatuhan mahasiswa dalam pembayaran pajak kendaraan bermotor.

Hubungan Kepercayaan pada Hukum dan Pemerintah dengan Kepatuhan Membayar Pajak Kendaraan Bermotor. Literatur tentang perpajakan tidak lepas dari pembahasan mengenai bagaimana keadaan suatu negara (hukum dan pemerintahan) dapat menciptakan pandangan bagi masyarakat yang berpengaruh terhadap patuh atau tidaknya masyarakat untuk membayar kewajiban pajaknya. Negara yang sedang dilanda krisis kepercayaan rakyat disebabkan oleh penegakan hukum yang kurang baik serta pemerintahan yang tidak mencermintan konstitusi yang benar. Permasalahan tersebut kemudian akan mempengaruhi tingkat kredibilitas pemerintah menjadi rendah sehingga rakyat enggan untuk percaya terhadap hukum dan pemerintah. Sejalan dengan pendapat di atas, Verboon dan Dijke (2011) mengungkapkan bahwa sanksi serta hukum pajak dapat meningkatkan kepatuhan para wajib pajak jika prosedur hukum dan sanksi tersebut mencerminkan implementasi yang adil sehingga membuat para wajib pajak percaya terhadap sistem hukum pajak yang diterapkan. Kepercayaan terhadap hukum tersebut nantinya akan meningkatkan kesadaran serta kepatuhan para wajib pajak untuk memenuhi kewajiban pajak mereka. Ketidakpercayaan rakyat terhadap mekanisme pemerintah dapat menyebabkan kesadaran untuk membayar pajak menjadi rendah. Dengan kata lain, masyarakat memandang bahwa untuk apa mereka mematuhi kewajiban membayar pajak jika hukum dan pemerintah tidak dapat dipercaya terutama jika berkaitan dengan tindak pidana korupsi yang terjadi. Uraian tersebut selanjutnya memberikan motivasi bagi peneliti untuk menghipotesiskan pengaruh dari kepercayaan mahasiswa terhadap hukum dan sistem perpajakan sebagai berikut: $\mathrm{H}_{3}$ : Tingkat kepercayaan mahasiswa terhadap hukum dan pemerintah berpengaruh positif terhadap kepatuhan mahasiswa dalam pembayaran pajak kendaraan bermotor.

Hubungan Persepsi Etis Pajak dengan Kepatuhan Membayar Pajak Kendaraan Bermotor. Persepsi etis dalam hal ini persepsi wajib pajak merupakan salah satu faktor yang mempengaruhi kepatuhan wajib pajak jika wajib pajak mengetahui akan pentingnya pajak dalam kehidupan bangsa dan negara maka wajib pajak tersebut akan mematuhi peraturan-peraturan yang berlaku mengenai pajak apalagi didalamnya terdapat sangsi perpajakan jika wajib pajak tidak patuh sehingga menimbulkan kepatuhan wajib pajak (Aristanti, 2011). Alm dkk. (2005) menerangkan bahwa moral pajak yang muncul dari
Tax Compliance and Its Perception Among Students

285 
Tax Compliance and Its Perception Among Students faktor-faktor kebijakan serta peraturan pemerintah tentang perpajakan nantinya akan menciptakan persepsi individu wajib pajak bahwa membayar pajak itu merupakan perilaku yang etis. Dengan kata lain, persepsi etis yang dimiliki oleh individu merupakan faktor penting dalam mempengaruhi kepatuhan pembayaran pajak sehingga penelitian ini mengajukan hipotesis sebagai berikut: $\mathrm{H}_{4}$ : Persepsi etis mahasiswa tentang perpajakan berpengaruh positif terhadap kepatuhan mahasiswa dalam pembayaran pajak kendaraan bermotor.

\section{METODE PENELITIAN}

Penelitian ini menggunakan model hubungan yang nantinya akan diuji untuk menginvestigasi peranan persepsi faktor internal individu mahasiswa yang memiliki kewajiban membayar pajak kendaraan pribadi serta pengaruhnya terhadap kepatuhan mereka untuk membayar pajak kendaraan. Pendekatan yang digunakan adalah jenis penelitian eksplanatori atau yang biasa disebut dengan explanatory research. Jenis penlitian ini merupakan penelitian kuantitatif dengan menggunakan metode survei atau menggunakan data primer berupa persepsi yang diperoleh langsung dari sumbernya (responden) dengan menggunakan self-administered survey. Teknik survei merupakan teknik penelitian yang mengumpulkan data melalui penggunaan angket yang bertujuan untuk memberikan pertanyaan dan mendapatkan jawaban dari sumbernya (Cooper dan Schindler, 2010). Penelitian ini menggunakan teknik pemilihan sampel melalui metode purposive sampling. Sugiyono (2012) mendefinisikan bahwa teknik purposive sampling merupakan teknik pengambilan sampel dari populasi dengan menentukan kriteria-kriteria yang ditentukan oleh peneliti dan dianggap relevan dengan tujuan penelitian. Sampel yang digunakan dalam penelitian ini adalah para mahasiswa yang merupakan wajib pajak kendaraan di Perguruan Tinggi skala Universitas di Kota Samarinda.

Pemilihan lokasi tersebut tidak tanpa alasan, mengingat bahwa kampus atau universitas merupakan perguruan tinggi yang memiliki mahasiswa dalam jumlah besar dibandingkan dengan perguruan tinggi berskala kecil (Sekolah Tinggi, Akademi dll.). Adapun kriteria sampel yang ditentukan oleh peneliti adalah (1) mahasiswa yang terdaftar aktif di universitas tempat mereka berkuliah, (2) memiliki kendaraan pribadi, (3) memiliki surat-surat kendaraan atas nama pribadi sebagai bukti hak kepemilikan atas kendaraan, (4) berusia minimal 18 tahun, serta (5) telah mengambil dan memahami mata kuliah perpajakan.

Penelitian ini bertujuan untuk menguji pengaruh dari faktor-faktor internal individu mahasiswa sebagai wajib pajak terhadap kepatuhan mereka membayar pajak kendaraannya. Adapun variabel yang diobservasi terbagi menjadi dua yaitu variabel dependen (Kepatuhan Membayar Pajak Kendaraan - Y) serta variabel independen yang terdiri dari empat faktor internal individu (X1, X2, X3 dan X4)

a. Kepatuhan Membayar Pajak Kendaraan. Kepatuhan dalam hal perpajakan berarti keadaan wajib pajak yang melaksanakan hak, khususnya kewajibannya, secara disiplin sesuai peraturan perundang-undangan serta tata cara perpajakan yang berlaku.

b. Persepsi atas Efektifitas Sistem Perpajakan. Persepsi yang baik atas efektifitas sistem perpajakan merupakan kesan yang dirasakan oleh wajib pajak terhadap sistem pembayaran pajak. Persepsi yang positif akan mendorong wajib pajak lebih memiliki kemauan dalam membayar pajak, sedangkan persepsi yang negatif akan berdampak sebaliknya. Modernisasi layanan pajak diharapkan dapat meningkatkan kepatuhan wajib pajak karena dapat mempermudah cara pembayaran dan pelaporan pajak.

c. Pengetahuan dan Pemahaman tentang Peraturan Perpajakan. Pengetahuan dan pemahaman tentang peraturan perpajakan adalah semua hal tentang perpajakan yang dimengerti dengan baik dan benar oleh wajib pajak. Pengetahuan tentang pajak ternyata mempengaruhi kesediaan orang untuk melaporkan pajak terutangnya. Hal ini tentunya akan membawa dampak positif bagi pemasukan negara, dimana wajib pajak akan selalu bertindak jujur dalam memenuhi kewajibannya serta berusaha untuk mematuhi peraturan perpajakan yang ada. Tanpa adanya pengetahuan tentang pajak dan manfaatnya, tidak mungkin orang akan tulus membayar pajak. 
d. Kepercayaan Wajib Pajak Terhadap Sistem Hukum dan Pemerintahan. Kepercayaan wajib pajak terhadap sistem hukum dan pemerintahan yang berlaku. Dalam hal ini tingkat kepercayaan setiap wajib pajak berbeda-beda sesuai penilaian masing-masing individu terhadap keadaan sistem hukum dan pemerintahan.

e. Persepsi Etis Tentang Kewajiban Membayar Pajak. Persepsi etis tentang kewajiban perpajakan berkaitan dengan bagaimana para wajib pajak memandang bahwa dengan membayar kewajiban pajaknya maka mereka telah berprilaku etis. Etika merupakan pernyataan benar atau salah yang menetukan perilaku seseorang tergolong bermoral atau tidak bermoral, baik atau buruk. Pernyataan etika ini kemudian dituangkan dalam bentuk prinsip-prinsip etika yang secara normatif dipergunakan untuk membimbing tindakan seseorang menjadi perilaku yang bermoral (Sigit, 2012).

\section{HASIL DAN PEMBAHASAN}

Pelaksanaan penelitian dilakukan pada lokasi tempat peneliti memperoleh informasi atau data yang berkaitan dengan konteks observasi dalam penelitian ini. Lokasi yang menjadi tempat tersebut adalah di beberapa perguruan tinggi berbentuk universitas di kota Samarinda. Penelitian yang tergolong jenis penelitian kuantitatif ini mengobservasi variabel-variabel faktor internal individu dalam mempengaruhi tingkat kepatuhan pembayaran kendaraan pada mahasiswa. Pemilihan responden mahasiswa dianggap sudah sesuai karena para mahasiswa tergolong representatif dari praktisi yang juga memiliki kewajiban dalam membayar pajak kendaraan ketika mereka memiliki kenadaraan bermotor atas nama pribadi mereka. Survei yang dilakukan terhadap mahasiswa di Kota Samarinda melalui kuesioner merupakan metode peneliti dalam memperoleh data berupa persepsi tentang fokus permasalahan yang diteliti. Hasil penyebaran kuesioner berupa respon terkumpul sebanyak 118 respon. Namun setelah melakukan analisis respon dengan menyesuaikan karakteristik sampel penelitian maka diperoleh 93 respon yang layak untuk digunakan dalam analisis lebih lanjut. Dengan kata lain, tingkat respon (respon rate) sebesar 78,81\% yang merupakan kategori yang sangat tinggi dalam penelitian ilmu sosial.

Ditinjau dari segi demografi, karakteristik responden dalam penelitian ini menunjukkan bahwa sebanyak 33,33\% berjenis kelamin perempuan dan sisanya $66,67 \%$ adalah laki-laki. Rentang usia responden juga bervariasi namun lebih didominasi oleh rentang usia $21-25$ tahun yaitu 76 orang $(81,34 \%)$. Selanjutnya, untuk status pekerjaan responden menunjukkan bahwa seluruh responden merupakan mahasiswa. Akan tetapi, dari total mahasiswa sebagai responden teradapat terdapat 14 orang yang merupakan mahasiswa pekerja.

Uji validitas dalam penelitian ini dilakukan dengan menggunakan analisis korelasi Bivariate Pearson (nilai r) yaitu dengan melihat signifikansi korelasi antara skor masingmasing item pernyataan dengan skor totalnya (Jika $r$ hitung $\geq r$ tabel, maka item tersebut dikatakan valid). Selain itu, analisis uji validitas juga melihat nilai $r$ yang dihasilkan ( $r-$ hitung) dibandingkan dengan $\mathrm{r}$ yang berada pada tabel atau $\mathrm{r}$-tabel serta meninjau nilai signifikansi yang digunakan $(5 \%$ atau 0,05$)$. Tabel 1 dibawah ini menyajikan hasil uji validitas untuk semua item/butir pernyataan dalam kuesioner penelitian.

Hasil uji validitas yang ditunjukkan pada tabel 1 di atas mengindikasikan bahwa seluruh item pernyataan yang merupakan indikator konstruk penelitian yang diobservasi berada dalam kategori valid dan dapat digunakan. Dalam tabel tersebut terlihat bahwa seluruh nilai $r$-hitung lebih besar dari r-tabel $(r<0,207)$ serta berada pada signifikansi di bawah 0,05 sehingga seluruh item dikatakan valid. Selain itu, tabel 1 di atas juga menunjukkan hasil uji reliabilitas instrumen penelitian. Uji reliabilitas dalam penelitian ini menggunakan analisis scale reability yang menunjukkan nilai cronbach's alpha untuk masing-masing konstruk. Nilai cronbach's alpha yang ditunjukkan untuk semua konstruk penelitian berada di atas 0,50 sehingga dapat dikatakan reliabel.
Tax Compliance and Its Perception Among Students 
Tax Compliance and Its Perception Among Students

288

\begin{tabular}{|c|c|c|c|c|c|c|}
\hline Variabel & $\begin{array}{c}\text { Cronbach's } \\
\text { alpha }\end{array}$ & Item & r-tabel & $\begin{array}{c}\text { Pearson } \\
\text { correlation }\end{array}$ & Sig. & Keterangan \\
\hline \multirow{5}{*}{$\begin{array}{l}\text { Persepsi } \\
\text { efektifitas sistem } \\
\text { perpajakan yang } \\
\text { baik }\end{array}$} & \multirow{5}{*}{$\begin{array}{c}0,660 \\
\text { (Reliabel) }\end{array}$} & EF1 & 0,207 & 0,664 & 0,00 & Valid \\
\hline & & EF2 & 0,207 & 0,767 & 0,00 & Valid \\
\hline & & EF3 & 0,207 & 0,744 & 0,00 & Valid \\
\hline & & EF4 & 0,207 & 0,734 & 0,00 & Valid \\
\hline & & EF5 & 0,207 & 0,670 & 0,00 & Valid \\
\hline \multirow{5}{*}{$\begin{array}{l}\text { Pengetahuan } \\
\text { Tentang } \\
\text { Peraturan } \\
\text { Perpajakan }\end{array}$} & \multirow{5}{*}{$\begin{array}{c}0,606 \\
\text { (Reliabel) }\end{array}$} & PP1 & 0,207 & 0,774 & 0,00 & Valid \\
\hline & & PP2 & 0,207 & 0,712 & 0,00 & Valid \\
\hline & & PP3 & 0,207 & 0,732 & 0,00 & Valid \\
\hline & & PP4 & 0,207 & 0,501 & 0,00 & Valid \\
\hline & & PP5 & 0,207 & 0,503 & 0,00 & Valid \\
\hline \multirow{4}{*}{$\begin{array}{l}\text { Kepercayaan } \\
\text { terhadap sistem } \\
\text { pajak dan } \\
\text { pemerintah }\end{array}$} & \multirow{4}{*}{$\begin{array}{c}0,807 \\
\text { (Reliabel) }\end{array}$} & KE1 & 0,207 & 0,826 & 0,00 & Valid \\
\hline & & KE2 & 0,207 & 0,841 & 0,00 & Valid \\
\hline & & KE3 & 0,207 & 0,809 & 0,00 & Valid \\
\hline & & KE4 & 0,207 & 0,719 & 0,00 & Valid \\
\hline Perspesi etis & \multirow{4}{*}{$\begin{array}{c}0,790 \\
\text { (Reliabel) }\end{array}$} & PE1 & 0,207 & 0,769 & 0,00 & Valid \\
\hline pajak tentang & & PE2 & 0,207 & 0,827 & 0,00 & Valid \\
\hline kewajiban pajak & & PE3 & 0,207 & 0,707 & 0,00 & Valid \\
\hline kendaraan & & PE4 & 0,207 & 0,858 & 0,00 & Valid \\
\hline \multirow{10}{*}{$\begin{array}{l}\text { Kepatuhan } \\
\text { pembayaran } \\
\text { pajak kendaraan }\end{array}$} & \multirow{10}{*}{$\begin{array}{c}0,907 \\
\text { (Reliabel) }\end{array}$} & KP1 & 0,207 & 0,820 & 0,00 & Valid \\
\hline & & KP2 & 0,207 & 0,753 & 0,00 & Valid \\
\hline & & KP3 & 0,207 & 0,856 & 0,00 & Valid \\
\hline & & KP4 & 0,207 & 0,808 & 0,00 & Valid \\
\hline & & KP5 & 0,207 & 0,849 & 0,00 & Valid \\
\hline & & KP6 & 0,207 & 0,706 & 0,00 & Valid \\
\hline & & KP7 & 0,207 & 0,852 & 0,00 & Valid \\
\hline & & KP8 & 0,207 & 0,812 & 0,00 & Valid \\
\hline & & KP9 & 0,207 & 0,735 & 0,00 & Valid \\
\hline & & KP10 & 0,207 & 0,607 & 0,00 & Valid \\
\hline
\end{tabular}

Sumber: Data olahan peneliti

Penelitian ini selanjutnya menggunakan pendekan uji asumsi klasik dengan tujuan untuk memperoleh hasil uji yang lebih baik. Pengujian asumsi klasik yang dilakukan adalah uji normalitas terhadap data penelitian. Uji normalitas dalam peneltian ini menggunakan pendekatan Kolmogrov-Smirnov yaitu dengan menilai signifikansi yang ditunjukkan pada uji tersebut. Jika nilai yang dihasilkan oleh asumsi signifikansi berada lebih besar dari batas minimum 0,50 maka dapat dikatakan data tersebut lolos asumsi normalitas. Pada tabel 2 dapat dilihat bahwa hasil uji normalitas nilai signifikansi yang ditunjukkan berada diatas 0.50 yaitu sebesar 0,799 . Hal ini kemudian memberikan indikasi bahwa seluruh data yang digunakan dalam penelitian ini adalah normal. Penelitian ini juga melakukan uji multikoleniaritas yang menunjukkan nilai tolerance dari semua variabel independen penelitian berada di atas 0.10 serta nilai VIF yang berada dibawah 10. Hal ini menyimpulkan bahwa dalam model regresi yang digunakan tidak terdapat masalah multikoleniaritas sehingga layak untuk digunakan sebagai model regresi penelitian.

Tabel 2. Hasil Uji Normalitas Data Penelitian

\begin{tabular}{llr}
\hline & & Unstandardized Residual \\
\hline $\mathrm{N}$ Normal Parameters & 93 \\
& & .0000000 \\
Most Extreme Differences & Mean & 4.87388978 \\
& Std. Deviation & .183 \\
& Absolute & .183 \\
& Positive & -.086 \\
Kolmogorov-Smirnov Z & Negative & 578 \\
Asymp. Sig. (2-tailed) & & .799 \\
\hline
\end{tabular}

$\begin{array}{ll}\text { a. Test distribution is Normal } & \text { b. Calculated from data }\end{array}$

Sumber: Output SPSS olahan data peneliti 
Pengujian terhadap seluruh hipotesis penelitian (H1-H4) dilakukan dengan metode statistik multiple regression atau analsisi regresi linear berganda. Persamaan regresi berganda yang digunakan dalam penelitian ini adalah sebagai berikut:

$$
\mathrm{KP}=\mathrm{a}+\mathrm{b}(\mathrm{EF})+\mathrm{b}(\mathrm{PP})+\mathrm{b}(\mathrm{KE})+\mathrm{b}(\mathrm{PE})+\mathrm{e}
$$

Tabel 3. Hasil Uji F Regresi Linear Berganda

\begin{tabular}{|c|c|c|c|c|c|c|}
\hline Model & & $\begin{array}{l}\text { Sum of } \\
\text { Squares }\end{array}$ & df & $\begin{array}{c}\text { Mean } \\
\text { Squares }\end{array}$ & $\mathbf{F}$ & Sig. \\
\hline \multirow{3}{*}{1} & Regression & 472.674 & 4 & \multirow{3}{*}{$\begin{array}{r}160.766 \\
16.265\end{array}$} & \multirow[t]{3}{*}{11.317} & \multirow[t]{3}{*}{$.001^{\mathrm{l}}$} \\
\hline & Residual & 1327.011 & 96 & & & \\
\hline & Total & 1799.683 & 99 & & & \\
\hline
\end{tabular}

a. Dependent variable: Kepatuhan Pembayaran Pajak Kendaraan

b. Predictors: (Constant), Efektifitas, Pemahaman, Kepercayaan, Persepsi Etis

Sumber: Output SPSS olahan data peneliti

Berdasarkan hasil yang ditunjukkan pada tabel 3 diatas, dapat terlihat bahwa hasil uji simultan atau uji $\mathrm{F}$ terhadap model regresi penelitian menunjukkan nilai $\mathrm{F}$ hitung sebesar 11.317 dengan signifikansi sebesar 0,001 < 0,05. Hasil tersebut mengindikasikan bahwa secara simultan perubahan yang terjadi pada variabel-variabel independen penelitian dapat mempengaruhi pada variabel dependen yaitu kepatuhan pembayaran pajak kendaraan. Dengan kata lain, variabel-variabel yang diobservasi dalam model regresi berganda penelitian ini telah menggambarkan kelayakan model yang baik untuk analisis statistic regresi linear berganda.

Tabel 4. Hasil Uji T Regresi Linear Berganda

\begin{tabular}{|c|c|c|c|c|c|}
\hline \multirow[t]{2}{*}{ Model } & \multicolumn{2}{|c|}{ Unstandardized Coefficeints } & \multirow{2}{*}{$\frac{\text { Standardized Coeff }}{\text { Beta }}$} & \multirow[t]{2}{*}{$\mathbf{t}$} & \multirow[t]{2}{*}{ Sig. } \\
\hline & B & Std. Error & & & \\
\hline (Constant) & 8.763 & 2.542 & & 2.650 & .001 \\
\hline Efektifitas & .285 & .087 & .090 & 3.118 & .000 \\
\hline 1 Pemahaman & .182 & .074 & .241 & 2.892 & .000 \\
\hline Kepercayaan & .099 & .127 & .220 & 3.870 & .002 \\
\hline Persepsi Etis & .478 & .081 & .347 & 4.212 & .001 \\
\hline
\end{tabular}

a. Dependent variable: Kepatuhan Pembayaran Pajak Kendaraan

Sumber: Output SPSS olahan data peneliti

Tabel 4 diatas menunjukkan hasil dari uji t atau dalam regresi berganda disebut sebagai uji parsial untuk mengetahui pengaruh masing-masing variabel independen terhadap variabel dependen atau dalam penelitian ini adalah kepatuhan pembayaran pajak kendaraan. Hasil uji t parsial tersebut memberikan nilai-nilai yang nantinya dapat digunakan untuk menyimpulkan terdukung tidaknya hipotesis dalam penelitian yang akan lebih dijelaskan pada bagian pembahasan nanti. Dengan demikian, persamaan regresi berganda yang dihasilkan berdasarkan output analisis adalah sebagai berikut:

$$
\mathrm{KP}=8,763+0,285(\mathrm{EF})+0,182(\mathrm{PP})+0,099(\mathrm{KE})+0,478(\mathrm{PE})+\mathrm{e}
$$

Hasil uji determinasi juga dapat dilihat pada tabel 5 di bawah. Nilai $\mathrm{R}^{2}$ yang ditunjukkan adalah sebesar 0,312 yang memberikan gambaran bahwa sebesar 31,2\% variabel kepatuhan pembayaran pajak kendaraan dijelaskan oleh variabel-variabel independen observasian.

Berdasarkan hasil analisis regresi linear berganda yang dilakukan memebrikan indikasi bahwa seluruh hipotesis dalam penelitian secara signifikan dan positif adalah terdukung. Pada hasil uji f secara simultan (tabel 3) menunjukkan bahwa variabel efektifitas sistem pajak $\left(\mathrm{X}_{1}\right)$, pemahaman terhadap peraturan pajak $\left(\mathrm{X}_{2}\right)$, Kepercayaan terhadap sistem pajak dan pemerintah $\left(\mathrm{X}_{3}\right)$ dan Persepsi etis pajak $\left(\mathrm{X}_{4}\right)$ secara bersama-sama mampu mempengaruhi kepatuhan pembayaran pajak kendaraan $(\mathrm{Y})$. Hal ini dilihat dari nilai $\mathrm{f}$ hitung yang memberikan hasil positif yaitu sebesar 11,317 serta signifkan $0.001(<0.05)$. 
Tax Compliance and Its Perception Among Students
Tabel 5. Hasil Uji Koefisien Determinasi

\begin{tabular}{cccc}
\hline Model & $\mathbf{R}$ & R-Square & Adjusted R-Squared \\
\hline 1 & $.621^{\mathrm{a}}$ & .312 & .296
\end{tabular}

a. Predictors: (Constant), Efektifitas, Pemahaman, Kepercayaan, Persepsi Etis

b. Dependent variable: Kepatuhan Pembayaran Pajak Kendaraan

Sumber: Output SPSS olahan data peneliti

Pada tabel 4, uji parsial dilakukan untuk melihat pengaruh dari masing-maisng variabel. Dapat dilihat bahwa nilai t hitung untuk variabel efektifitas adalah sebesar 3,118 dan berada pada signifikansi dibawah 0.05 sehingga dapat disimpulkan secara positif dan signifikan hipotesis 1 terdukung. Begitu juga variabel pemahaman dan kepercayaan pada sistem pajak dan pemerintah yang masing-miasng menunjukkan nilai $t$ hitung positif $(2,892$ dan 3,870$)$ dan signifikan pada level dibawah 0,05 sehingga dapat disimpulkan hipotesis 2 dan 3 penelitian terdukung. Selanjutnya, hasil uji t juga memberikan gambaran mengenai keterdukungan terhadap hipotesis 4 penelitian. Dilihat pada tabel 4 tersebut yang menunjukkan nilai t hitung untuk variabel perspesi etis adalah sebesar 4,212 dan signifikan sebesar $0,001<0,05$. Hal ini menggambarkan bahwa persepsi etis pajak secara positif dan signifikan berpengaruh terhadap kepatuhan pembayaran pajak kendaraan atau dengan kata lain hipotesis terakhir penelitian ini terdukung. Secara keseluruhan, hasil pengujian hipotesis penelitian ini dapat dilihat pada tabel 6 di bawah ini.

Tabel 6. Rekapitulasi Hasil Uji Hipotesis Penelitian

\begin{tabular}{clcc}
\hline Hipotesis & \multicolumn{1}{c}{ Variabel } & Hubungan & Hasil \\
\hline H1 & $\begin{array}{l}\text { Efektifitas sistem pajak } \rightarrow \text { Kepatuhan pajak } \\
\text { kendaraan }\end{array}$ & Positif & Terdukung \\
\hline H2 & $\begin{array}{l}\text { Pemahaman aturan pajak } \rightarrow \text { Kepatuhan pajak } \\
\text { kendaraan }\end{array}$ & Positif & Terdukung \\
\hline H3 & $\begin{array}{l}\text { Kepercayaan pada hukum \& pemerintah } \rightarrow \\
\text { Kepatuhan pajak kendaraan }\end{array}$ & Positif & Terdukung \\
\hline H4 & Persepsi etis pajak $\rightarrow$ Kepatuhan pajak kendaraan & Positif & Terdukung \\
\hline
\end{tabular}

Berdasarkan hasil pengujian secara statistik terhadap semua hipotesis penelitian, dapat diterangkan bahwa hipotesis yang diajukan dalam penelitian ini memiliki keterdukungan hasil secara statistik serta sejalan dengan teori dan/atau hasil penelitian-penelitian terdahulu. Hipotesis pertama (H1) penelitian yang mencoba menginvestigasi pengaruh positif dari persepsi efektifitas sistem pajak terhadap kepatuhan pembayaran pajak menunjukkan hasil yang terdukung. Hasil tersebut mengkonfirmasi temuan penelitian Nuzul (2015) dan Indrawan (2014) yang membuktikan bahwa persepsi individu terhadap efektifitas sistem perpajakan yang baik dapat mempengaruhi willingness to pay taxes atau kepatuhan pajak individu.

Selanjutnya, pengaruh tingkat pemahaman dan pengetahuan tentang peraturan perpajakan terhadap kepatuhan pembayaran pajak kendaraan mahasiswa yang dihoptesiskan melalui hipotesis kedua (H2) juga memberikan keterdukungan hasil yang positif dan signifikan. Penelitian yang dilakukan oleh Ghoni (2012) menunjukkan bahwa tingkat kedisiplinan pembayaran pajak seseorang didasari oleh tingkat pemahamannya terhadap peraturan perpajakan yang ada. Sehingga, pemahaman dan pengetahuan mengenai peraturan perpajakan yang berpengaruhi terhadap kepatuhan pembayaran pajak kendaraan dalam penelitian ini juga sejalan dengan temuan penelitian Ghoni (2012).

Sanksi dan hukum yang digunakan untuk mengatur perpajakan suatu negara akan berdampak pada peningkatan kepatuhan pajak warganya (Verboon dan Dijke, 2011). Pandangan tersebut kemudian dihipotesiskan dalam penelitian ini (H3) dan menunjukkan keterdukungan hasil bahwa tingkat kepercayaan pada hukum dan pemerintah berpengaruh pada tingkat kepatuhan pajak seseorang. Dengan kata lain, mahasiswa yang percaya pada hukum yang ditegakkan secara maksimal serta pemerintah 
yang konsisten mengatur perpajakan kendaraan, akan memberikan persepsi yang positif bagi mahasiswa serta dapat meningkatkan kepatuhan pajak kendaraan mereka.

Pada hipotesis keempat $(\mathrm{H} 4)$, peneliti ini menginvestigasi pengaruh dari persepsi etis pajak mahasiswa terhadap kepatuhan pembayaran pajak kendaraan mereka. Berdasarkan hasil pengujian secara statistik, ditemukan keterdukungan terhadap hipotesis tersebut sehingga hal ini sejalan dengan penelitian sebelumnya yang menyebutkan bahwa persepsi etis pajak yang muncul dari faktor-faktor kebijakan serta peraturan pemerintah tentang perpajakan nantinya akan menciptakan persepsi individu wajib pajak bahwa membayar pajak itu merupakan perilaku yang etis (Arm dkk., 2005). Oleh karena itu, mahasiswa yang memiliki tingkat persepsi etis pajak yang baik, atau menganggap bahwa mematuhi pembayaran pajak kendaraan adalah suatu perilaku etis, akan menunjukkan sikap kepatuhan pembayaran pajak kendaraan yang baik pula.

\section{PENUTUP}

Pajak kendaraan bermotor merupakan pajak atas kepemilikan dan atau penguasaan atas kendaraan bermotor yang dimiliki pribadi ataupun badan. Pengelolaan terhadap pajak kendaraan bermotor sangat penting mengingat pajak merupakan pendapatan negara terbesar yaitu $85,11 \%$ berdasaarkan data dari APBN Indonesia tahun 2017. Akan tetapi, belum diketahui secara pasti bagaimana tingkat kepatuhan para wajib pajak kendaraan. Penelitian sebelumnya menunjukkan bahwa kesadaran dalam membayar pajak kendaraan masih belum mencapai tingkatan yang sesuai harapan negara.

Dengan menggunakan mahasiswa sebagai subyek penelitian dengan metode suvei di Kota Samarinda, peneliti bertujuan untuk menginvestigasi persepsi kepatuhan individu wajib pajak kendaraan dalam membayar pajak mereka. Obsevasi yang dilakukan dalam penelitian ini adalah dengan melihat bagaimana factor-faktor internal individu mahasiswa seperti persepsi efektifitas sistem pajak, pemahaman tentang peraturan pajak, kepercayaan terhadap sistem pajak dan pemerintah serta perspesi etis pajak yang dimiliki. Berdasarkan hasil analisis data yang diperoleh dari persepsi dalam respon kuesioner penelitian, secara keseluruhan, faktor-faktor tersebut berpengaruh secara positif dan signifikan terhadap kepatuhan pembayaran pajak kendaraan.

Mahasiswa yang menganggap bahwa penerapan sistem pajak kendaraan sudah efektif akan berorientasi patuh untuk membayar pajak yang mereka miliki. Begitu juga dengan mahasiswa yang memiliki pemahaman yang baik mengenai peraturan perpajakan. Selain itu, mereka yang percaya terhadap sistem pajak akan diterapkan dengan baik oleh pemerintah juga akan patuh dalam pembayaran pajak kenadraan pribadinya. Tak terkecuali dengan mahasiswa yang memiliki persepsi etis pajak yang baik. Mereka yang menganggap bahwa menghindari pajak adalah hal yang kurang etis makan akan patuh dalam melakukan pembayaran pajak kendaraan mereka.

\section{DAFTAR PUSTAKA}

Abrahams, N. B. dan Kristanto, A. B. (2016). Persepsi Calon Wajib Pajak dan Wajib Pajak Terhadap Penggelapan Pajak di Salatiga. Berkala Akuntansi dan Keuangan Indonesia.

Alm, J. V. dan Torgler, B. (2005). Russian Attitudes Toward Paying Taxes-Before, During, and After The Transition. Journal of Public Economics.

Arum, H.P. 2012. Pengaruh Kesadaran Wajib Pajak, Pelayanan Fiskus, dan Sanksi Pajak terhadap Kepatuhan Wajib Pajak Orang Pribadi yang Melakukan Kegiatan Usaha Dan Pekerjaan Bebas Diwilayah KPP Pratama Cilacap. Skripsi Sarjana Fakultas Ekonomika dan Bisnis Universitas Diponegoro

Anwar, A.D. and Amyar, F., 2020. Analisis Faktor-Faktor Yang Mempengaruhi Kualitas Audit Internal Dalam Pengambilan Keputusan Laporan Keuangan Pada PT Damar Bandha Jaya Bogor. Jurnal Ilmiah Akuntansi Kesatuan, 8(1), pp.87-96.
Tax Compliance and Its Perception Among Students

291 
Tax Compliance and Its Perception Among Students
Fitria, A. and Munawar, A., 2021. Pengaruh Penggunaan Internet Banking, Mobile Banking Dan SMS Banking Terhadap Kepuasan Nasabah Bank BNI. Jurnal Informatika Kesatuan, 1(1), pp.41-50.

Cooper, D. R., and Schindler, P. S. (2010). Business Research Methods. New York: McGraw-Hill.

Iriyadi, I., Setiawan, B. and Sutarti, S., 2017. Pelatihan Analisis Data Penelitian (Primer Dan Sekunder) Bagi Mahasiswa Kesatuan. Jurnal Abdimas, 1(1), pp.1-4.

Lubis, Irwansyah. (2010) Review Pajak: Orang Pribadi dan Orang Asing. Jakarta: Salemba Empat.

Mardiasmo. (2011). Perpajakan. Edisi Revisi. Yogyakarta: Andi Ofset.

Mulyana, M., 2012. Consumer Behaviour: Sukses Dengan Memahami Konsumen.

Roseline, Riessa. 2012. Analisis Faktor-Faktor yangMempengaruhi Kepatuhan Wajib Pajak dalam Mengukuhkan Diri sebagai Pengusaha Kena Pajak. Skripsi. Malang: Universitas Brawijaya.

Siahaan, M. P. (2013) Hukum Pajak Material. Yogyakarta: Graha Ilmu.

Sigit, T. H. (2012). Etika Bisnis Modern: Pendekatan Pemangku Kepentingan. Yohyakarta: UPP STIM YKPN.

Sugiyono. (2012). Metode Penelitian Kauntitatif, Kualitatif, dan R\&D. Bandung: Alfabeta.

Undang-undang Nomor 28 Tahun 2007 Tentang Ketentuan Umum dan Tata Cara Perpajakan

Undang-undang Nomor 28 Tahun 2009 Tentang Pajak Daerah dan Retribusi

Untung, H. B. (2012). Hukum dan Etika Bisnis. Yogyakarta: Andi Ofset.

Verboon, P. dan van Dijke, M. 2011. When Do Severe Sanctions Enhance Compliance? The Role of Procedural Fairness. Journal pf Economic Psychology. 